\title{
УДК 621.331.3
}

\section{В. Г. СИЧЕНКО (ДНУЗТ), Є. М. КОСАРЕВ (ДНУЗТ), М. М. ПУЛІН (РЕГІОНАЛЬНА ФІЛІЯ «ЛЬВІВСЬКА ЗАЛІЗНИЦЯ» ПАТ «УКРЗАЛІЗНИЦЯ»)}

Дніпропетровський національний університет залізничного транспорту імені академіка В. Лазаряна 49010, Дніпро, вул. Лазаряна, 2, тел. +38(056) 793-19-11, e-mail: elpostz@i.ua

Дніпропетровський національний університет залізничного транспорту імені академіка В. Лазаряна 49010, Дніпро, вул. Лазаряна, 2, тел. +38(056) 793-19-11, e-mail: kosarev@e.diit.edu.ua, http://orcid.org/0000-0003-3574-7414

Регіональна філія «Львівська залізниця» ПАТ «Укрзалізниця», 79000 Україна, Львів, вул. Гоголя, 1

\section{ЯКІСТЬ ЕЛЕКТРИЧНОЇ ЕНЕРГІЇ НА ШИНАХ 10 КВ ПРИ ПАРАЛЕЛЬНІЙ РОБОТІ ТЯГОВОЇ ПІДСТАНЦІї 3 СОНЯЧНОЮ ЕЛЕКТРОСТАНЦЕЮ}

\section{Вступ}

Застосування сонячних електростанцій (CEC) у системах електропостачання промислових та побутових споживачів на сьогодні $\epsilon$ незаперечним фактом. При цьому одним з головних векторів розвитку сучасної електроенергетики є еволюційний перехід від централізованої генерації електричної енергії до розподілених смарт-систем генерації, що використовують поновлювані джерела енергії. Їх застосування збільшує маневреність потоків енергії, що призводить до підвищення якості електропостачання в умовах нерівномірних графіків споживання електричної енергії. Застосування розподілених систем генерації і накопичення електричної енергії дозволяє понизити матеріаломісткість електроенергетичних систем, збільшити іiі надійність і живучість за рахунок резервної енергії, запасеної в накопичувачах. Загальна доля рівня генерованованої СЕС енергії щорічно збільшується, при цьому необхідно також звернути увагу на те, що 32010 р. собівартість електричної енергії, виробленої СЕС $€$ меншою, ніж виробленої на атомних електростанціях.

Інтеграція джерел розподіленої генерації (ДРГ) в систему тягового електропостачання постійного струму вимагає розробки нових принципів проектування, функціонування і управління режимами роботи тягового електропостачання [1]. Необхідність їх розробки обумовлена наступними чинниками: змінюється структура електричної системи, потужність генерації ДРГ визначається зовнішніми чинниками (в першу чергу інтенсивністю сонячного випромінювання і вітрового потоку) і мало залежить від режиму роботи електричної мережі, до якої вони приєднані, установки ДРГ можуть мати коливальний або переривчастий характер генерації потужності, яка може привести до сильних коливань потужності в системі і впливати на режими іiї роботи, більшість ДРГ приєднані до мережі за допомогою силових електронних перетворювачів (інверторів), які дуже чутливі до рівнів напруг. Звідси, необхідно вирішувати низку запитань: визначення впливу ДРГ на стабільність роботи тягових підстанцій, тягових і інших споживачів, які приєднані до шин тягової підстанції 3 урахуванням допустимих режимів роботи споживачів, розробка рекомендацій відносно особливостей приєднання цього типу генерації до електричних мереж залізниць, функціонування пристроїв релейного захисту і автоматики, забезпечення необхідного рівня надійності електропостачання споживачів 3 необхідними якісними характеристиками, типу вживаного накопичувача і місця його установки. На сьогоднішній вирішення вказаних завдань здійснюється 3 застосуванням смарт-технологій, одним із завдань яких $\epsilon$, тому числі, забезпечення якості електричної енергії.

\section{Аналіз останніх досліджень}

Інтеграція СЕC в існуючі системи електропостачання поряд 3 широким застосуванням пристроїв силової електроніки змінює характер енергообмінних та перехідних процесів, що призводить до зміни балансу електричної енергії, виникнення потужностей спотворення та пульсацій, зміни рівнів напруги та погіршення якості електричної енергії [2-5]. Необхідно приймати до уваги той факт, що силові інвертори, через які приєднуються СЕС, чутливі до рівнів напруги і при неналежному підключенні в залежності від конфігурації мережі, iii хвильових властивостей, складу та

(C) Сиченко В. Г. та ін., 2017 
стану застосовуваного обладнання це може привести до порушення стійкості паралельної роботи діючої системи електропостачання та CEC. Значний вплив на характер паралельної роботи має потужність взаємодіючих систем. Саме тому в роботі [6] було рекомендовано здійснювати підключення СЕС до шин високої напруги. В Україні для перетворення електричної енергії, виробленої СЕС, застосовуються енергоефективні інвертори провідних світових виробників. Зокрема, на досліджуваній СЕС, приєднаній до шин 10 кВ тягової підстанції встановлені інвертори фірми KACO, які мають наступні технічні характеристики:

Таблиця 1

Технічні характеристики інверторів Powador, TM KACO New Enrrgy

\begin{tabular}{|c|c|c|c|c|}
\hline Модель інвертора & 12.0 TL3 & 14.0 TL3 & 18.0 TL3 & 20.0 TL3 \\
\hline \multicolumn{5}{|l|}{ DC вхід } \\
\hline $\begin{array}{l}\text { Робочий діапазон } \\
\text { напруги, В }\end{array}$ & $200-950$ & $200-950$ & $200-950$ & $200-950$ \\
\hline $\begin{array}{l}\text { Напруга неробо- } \\
\text { чого ходу, В }\end{array}$ & 1000 & 1000 & 1000 & 1000 \\
\hline $\begin{array}{l}\text { Максимальний } \\
\text { вхідний струм, A }\end{array}$ & $2 \times 18,6$ & $2 \times 18,6$ & $2 \times 18,6$ & $2 \times 18,6$ \\
\hline $\begin{array}{l}\text { Максимальна по- } \\
\text { тужність, кВт }\end{array}$ & 10,2 & 12,8 & 14,9 & 14,9 \\
\hline \multicolumn{5}{|l|}{ АС вихід } \\
\hline $\begin{array}{l}\text { Номінальна вихі- } \\
\text { дна потужність } \\
\text { при } 230 \text { В, кВА }\end{array}$ & 10 & 12,5 & 15 & 17 \\
\hline $\begin{array}{l}\text { Номінальний } \\
\text { струм, А }\end{array}$ & $3 \times 14,5$ & $2 \times 18,1$ & $2 \times 21,8$ & $2 \times 24,6$ \\
\hline $\begin{array}{l}\text { Номінальна час- } \\
\text { тота, Гц }\end{array}$ & $50 / 60$ & $50 / 60$ & $50 / 60$ & $50 / 60$ \\
\hline $\cos \varphi$ & 0,8 інд...0,8 ємН & 0,8 інд...0,8 ємн & 0,8 інд... $0,8 \in \mathrm{\epsilon мH}$ & 0,8 інд...0,8 ємн \\
\hline ККД, \% & 98,0 & 98,0 & 98,0 & 97,9 \\
\hline $\begin{array}{l}\text { Коефіцієнт спо- } \\
\text { творення, \% }\end{array}$ & $<3$ & $<3$ & $<3$ & $<3$ \\
\hline
\end{tabular}

Метюю даної роботи $\epsilon$ дослідження показників якості електричної енергії (ПЯЕ) на шинах 10 кВ тягової підстанції, до яких підключена СЕС.

\section{Методологія проведення експерименту}

Оскільки дослідження ПЯЕ базуються на застосуванні статистичних методів обробки та аналізу експериментальних даних, отриманих як в результаті фізичного експерименту, так і в результаті математичного моделювання експериментальні дослідження виконувались згідно розробленої на кафедрі “Інтелектуальні системи електропостачання” методики 3 використанням розробленого програмно-апаратного комплексу [7].

Схему вимірювання показників якості електроенергії наведено на рис. 1. В процесі експериментальних досліджень оцінювались такі показники якості електричної енергії:

- рівень та відхилення напруги;

- коефіцієнт несиметрії за зворотною послідовністю;

(C) Сиченко В. Г. та ін., 2017
- коефіцієнт спотворення синусоїдності напруги.

Додатково виконувалась оцінка коефіцієнта спотворення синусоїдності струму.

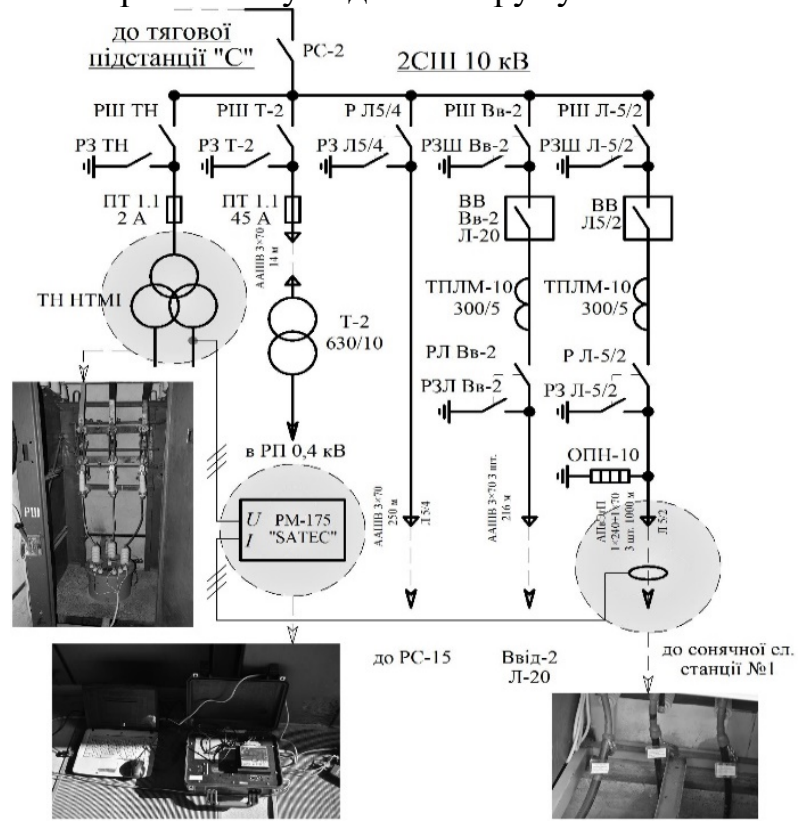

Рис. 1. Схема підключення вимірювальних приладів 


\section{Результати експериментальних} досліджень та їх аналіз

Вимірювання проводились в РП-10 кВ ТП-5 ст. «С» Львівської залізниці на вводі від сонячної електростанції (рис. 1). За результатами вимірювань побудовано графіки зміни параметрів електричної енергії впродовж доби.

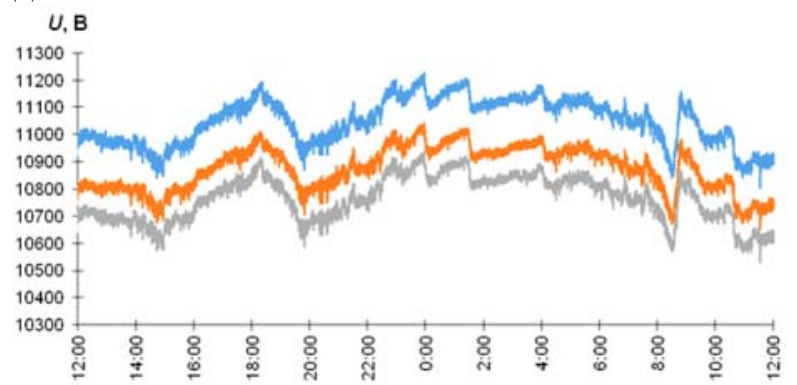

Рис. 2. Напруга на вводі РП-10 кВ ТП-5 сонячної електростанції

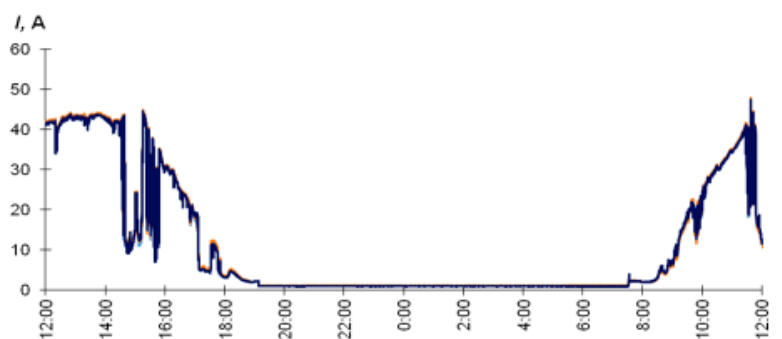

Рис. 3. Струм на вводі РП-10 кВ ТП-5 сонячної електростанції

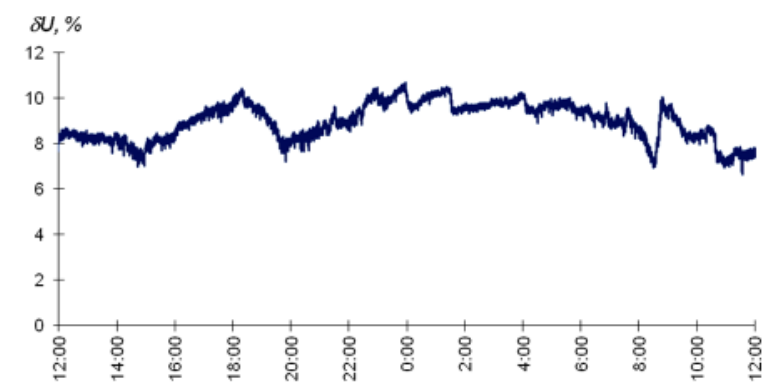

Рис. 4. Відхилення напруги на вводі РП-10 кВ ТП-5 сонячної електростанції

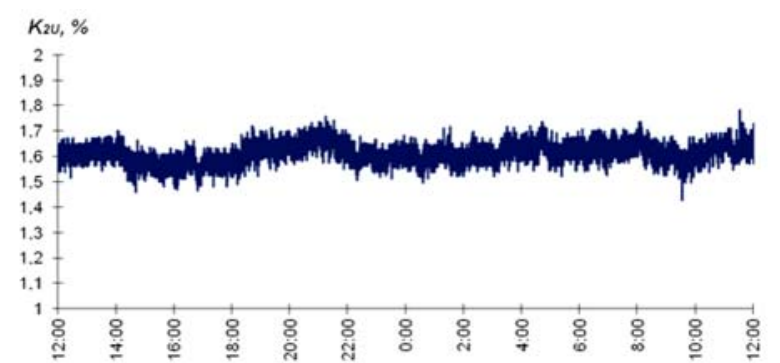

Рис. 5. Коефіцієнт несиметрії напруги за зворотною послідовністю на вводі РП-10 кВ ТП-5 сонячної електростанції

Як видно 3 рис. 4 усталене відхилення напруги за весь час проведення експерименту перевищувало нормально допустиме значення 5\%, а в період $з$ 18:00 до 08:00 (неробоча СЕС) сягало більше $10 \%$, виходячи за межі гранично допустимого значення. Коефіцієнт несиметрії напруги за зворотною послідовністю знаходився в межах допустимих значень (рис. 5).

Генерація електроенергії сонячною електростанцією відбувалась протягом світлового дня 3 08:00 до 18:00, графіки потужностей зображені на рис. $6-8$.

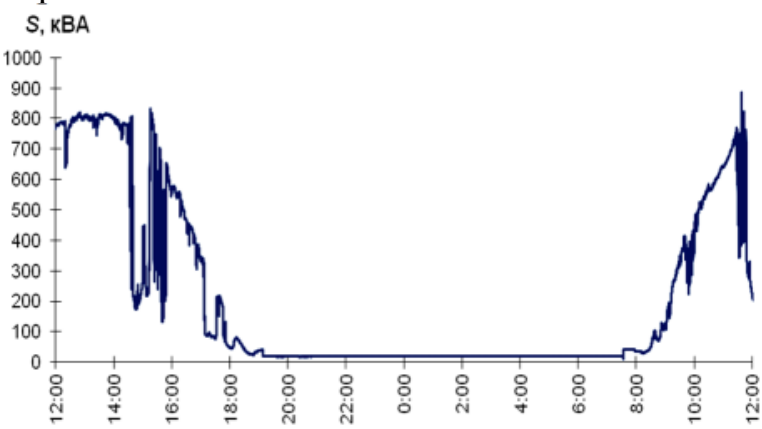

Рис. 6. Повна потужність на вводі РП-10 кВ ТП-5 сонячної електростанції

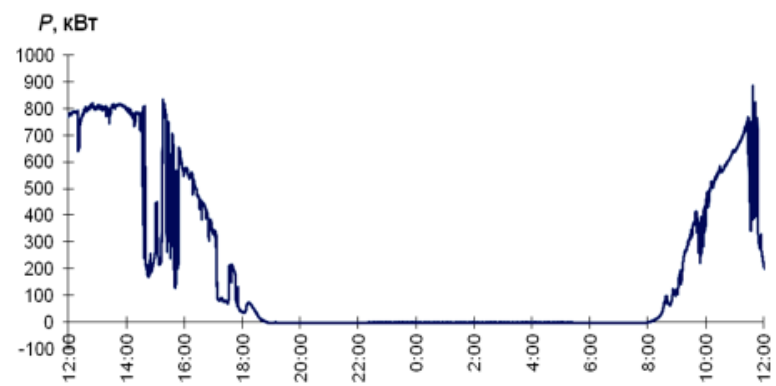

Рис. 7. Активна потужність на вводі РП-10 кВ ТП-5 сонячної електростанції

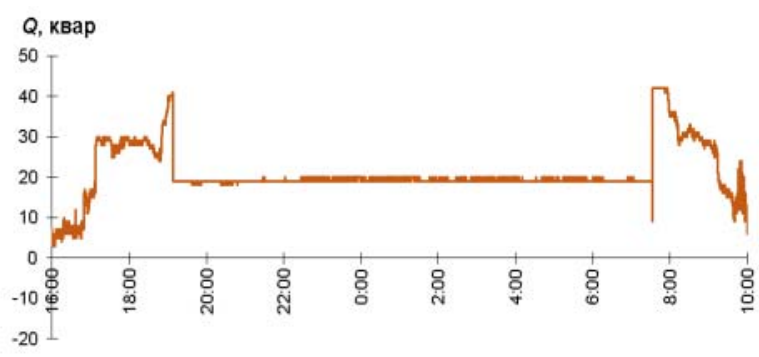

Рис. 8. Реактивна потужність на вводі РП-10 кВ ТП5 сонячної електростанції

Коефіцієнт спотворення синусоїдальності кривої напруги (рис. 9) за час вимірювань знаходився в межах допустимих значень. Значні сплески коефіцієнта спотворення синусоїдальності кривої струму спостерігалися лише в момент ввімкнення та вимкнення сонячної електростанції в роботу (рис. 10). 


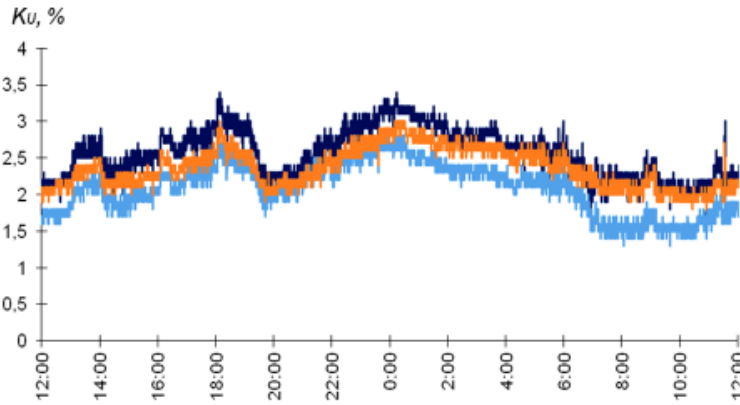

Рис. 9. Коефіцієнт спотворення синусоїдальності кривої напруги на вводі РП-10 кВ ТП-5 сонячної електростанції

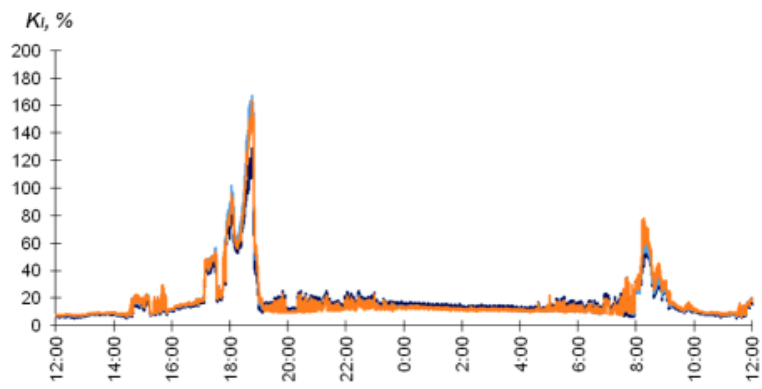

Рис. 10. Коефіцієнт спотворення синусоїдальності кривої струму на вводі РП-10 кВ ТП-5 сонячної електростанції

Результати статистичної обробки отриманих експериментальних даних наведені на рис. 11-16 та зведені в табл. 2-4.

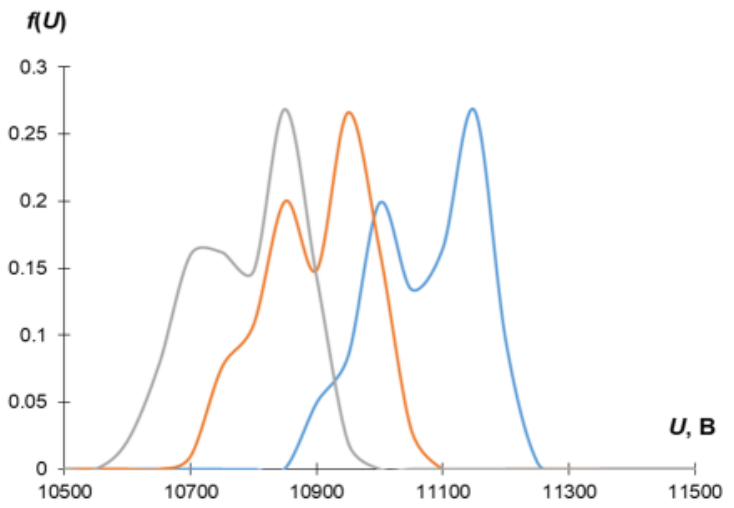

Рис. 11. Розподіл щільності імовірності напруги

$F(U)$

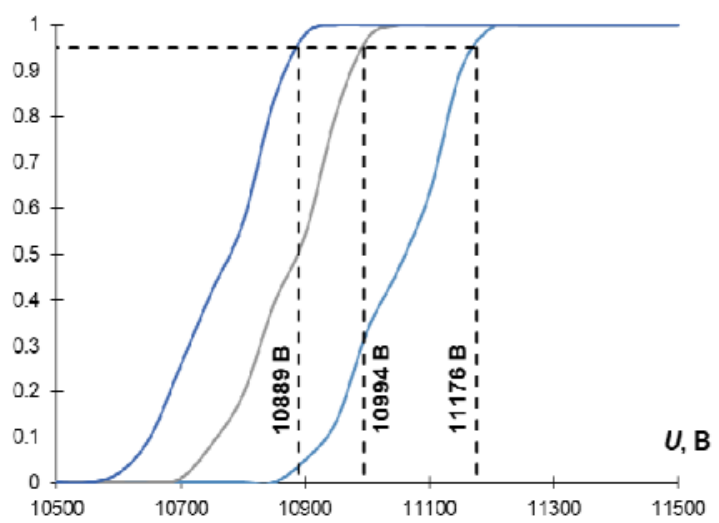

Рис. 12. Кумулятивна крива імовірності напруги

(C) Сиченко В. Г. та ін., 2017
Таблиця 2

Числові характеристики напруги

\begin{tabular}{|l|c|c|c|}
\hline Параметр & $\boldsymbol{U}_{\boldsymbol{A}}$ & $\boldsymbol{U}_{\boldsymbol{B}}$ & $\boldsymbol{U}_{\boldsymbol{C}}$ \\
\hline $\mathrm{M}(\mathrm{Ku}), \mathrm{B}$ & 11048.72 & 10874.22 & 10765.46 \\
\hline $\mathrm{Mo}(\mathrm{Ku}), \mathrm{B}$ & 11114.73 & 10933.93 & 10827.54 \\
\hline $\mathrm{Me}(\mathrm{Ku}), \mathrm{B}$ & 11058.45 & 10884.61 & 10773.85 \\
\hline $\mathrm{D}(\mathrm{Ku}), \mathrm{B}^{2}$ & 7076.27 & 6531.68 & 6839.72 \\
\hline $\mathrm{s}(\mathrm{Ku}), \mathrm{B}$ & 84.12 & 80.82 & 82.70 \\
\hline $\mathrm{As}(\mathrm{Ku})$ & -0.26 & -0.30 & -0.26 \\
\hline $\mathrm{Ex}(\mathrm{Ku})$ & -0.97 & -0.92 & -0.95 \\
\hline $\min (\mathrm{Ku}), \mathrm{B}$ & 10803.90 & 10652.73 & 10531.22 \\
\hline $\max (\mathrm{Ku}), \mathrm{B}$ & 11225.59 & 11040.51 & 10937.54 \\
\hline $\mathrm{U}(0.95), \mathrm{B}$ & 11176.14 & 10993.57 & 10889.34 \\
\hline $\boldsymbol{H}(\mathbf{c})$ & & &
\end{tabular}

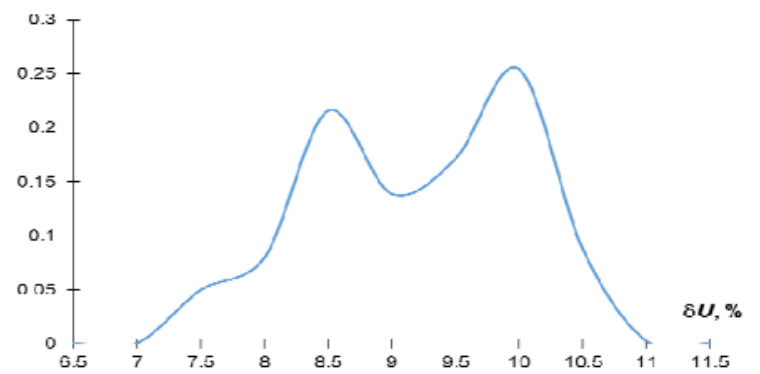

Рис. 13. Розподіл щільності імовірності відхилення напруги

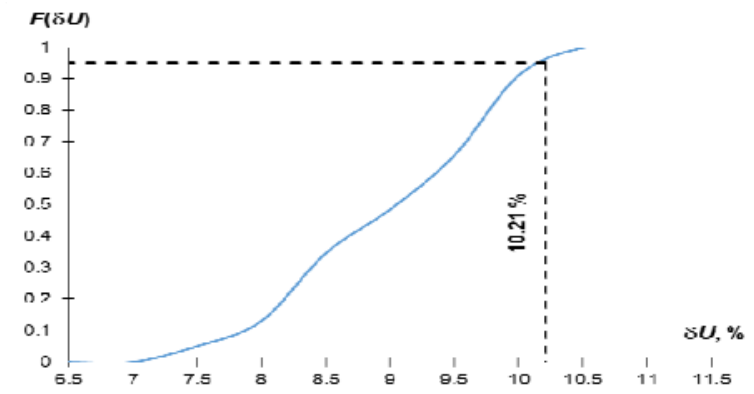

Рис. 14. Кумулятивна крива імовірності відхилення напруги

Таблиця 3

Числові характеристики відхилення напруги

\begin{tabular}{|l|c|}
\hline \multicolumn{1}{|c|}{ Параметр } & $\delta \boldsymbol{U}$ \\
\hline $\mathrm{M}(\delta \mathrm{U}), \%$ & 8.96 \\
\hline $\mathrm{Mo}(\delta \mathrm{U}), \%$ & 9.58 \\
\hline $\mathrm{Me}(\delta \mathrm{U}), \%$ & 9.07 \\
\hline $\mathrm{D}(\delta \mathrm{U}), \%$ \% & 0.68 \\
\hline $\mathrm{s}(\delta \mathrm{U}), \%$ & 0.82 \\
\hline $\mathrm{As}(\delta \mathrm{U})$ & -0.27 \\
\hline $\operatorname{Ex}(\delta \mathrm{U})$ & -0.95 \\
\hline $\min (\delta \mathrm{U}), \%$ & 6.64 \\
\hline $\max (\delta \mathrm{U}), \%$ & 10.67 \\
\hline$\delta \mathrm{U}(0.95), \%$ & 10.21 \\
\hline
\end{tabular}




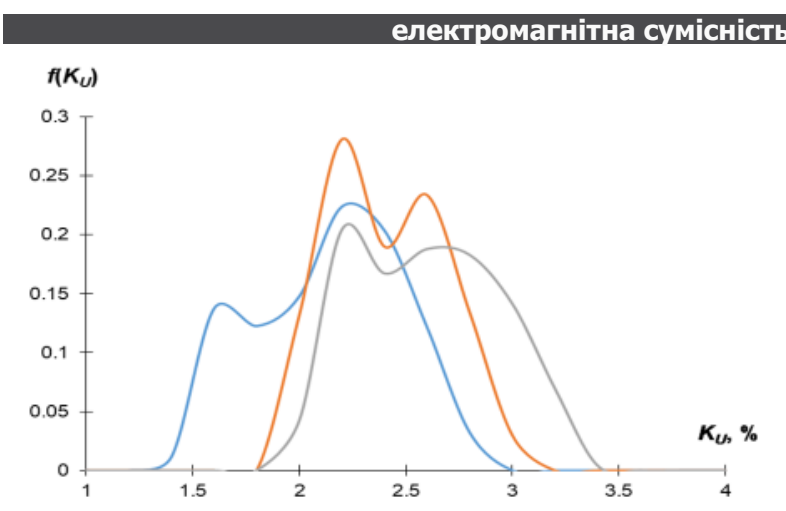

Рис. 15. Розподіл щільності імовірності коефіцієнта спотворення синусоїдальності кривої напруги

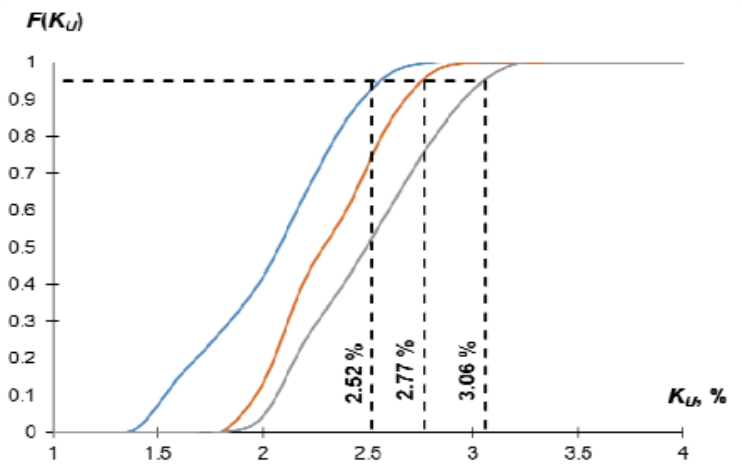

Рис. 16. Кумулятивна крива імовірності коефіцієнта спотворення синусоїдальності кривої напруги

Таблиця 4

Числові характеристики коефіцієнта спотворення синусоїдальності кривої напруги

\begin{tabular}{|l|c|c|c|}
\hline Параметр & K $_{\mathbf{U A}}$ & $\mathbf{K}_{\mathbf{U B}}$ & $\mathbf{K}_{\mathbf{U C}}$ \\
\hline $\mathrm{M}(\mathrm{Ku}), \%$ & 2.09 & 2.36 & 2.55 \\
\hline $\mathrm{Mo}(\mathrm{Ku}), \%$ & 2.20 & 2.10 & 2.20 \\
\hline $\mathrm{Me}(\mathrm{Ku}), \%$ & 2.10 & 2.30 & 2.60 \\
\hline $\mathrm{D}(\mathrm{Ku}), \%{ }^{2}$ & 0.12 & 0.07 & 0.11 \\
\hline $\mathrm{s}(\mathrm{Ku}), \%$ & 0.34 & 0.27 & 0.33 \\
\hline $\mathrm{As}(\mathrm{Ku})$ & -0.18 & 0.23 & 0.14 \\
\hline $\mathrm{Ex}(\mathrm{Ku})$ & -0.90 & -1.03 & -1.02 \\
\hline $\min (\mathrm{Ku}), \%$ & 1.30 & 1.80 & 1.70 \\
\hline $\max (\mathrm{Ku}), \%$ & 2.90 & 3.00 & 3.40 \\
\hline $\mathrm{Ku}(0.95), \%$ & 2.52 & 2.77 & 3.06 \\
\hline
\end{tabular}

Статистичний аналіз даних показав, що лише усталене відхилення напруги не відповідає вимогам [8] (рис. 12), всі інші досліджувані показники знаходяться в межах нормованих значень.

3 аналізу гармонійного складу напруги (рис. 17 - 19) видно, що при роботі СЕС спостерігається менша емісія гармонік та зниження їх амплітуди. При вимкненій СЕС амплітуда гармонік зростає та 3'являються $11,13,17,19$ та 25 гармонійні складові. Значний вміст у спектрі напруги 3 та 5 гармоніки пояснюється схемою застосовуваного інверторного перетворювача.

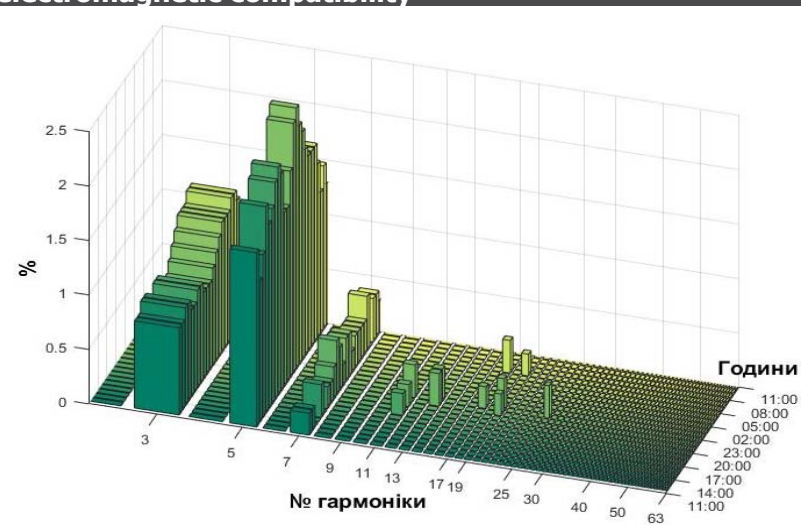

Рис. 17. Спектральний склад напруги фази «A»

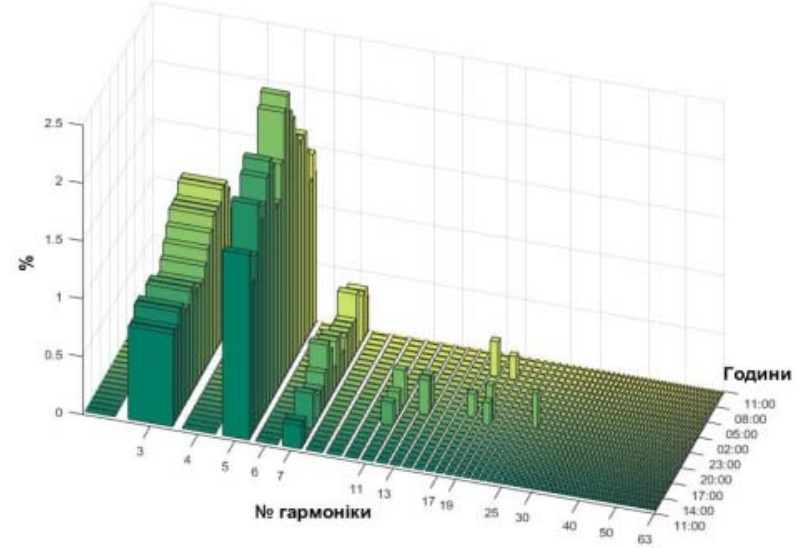

Рис. 18. Спектральний склад напруги фази «B»

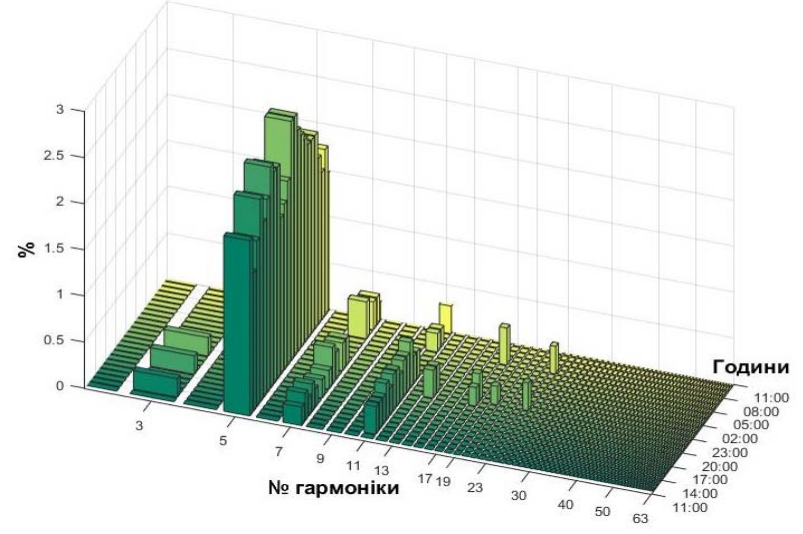

Рис. 19. Спектральний склад напруги фази «С»

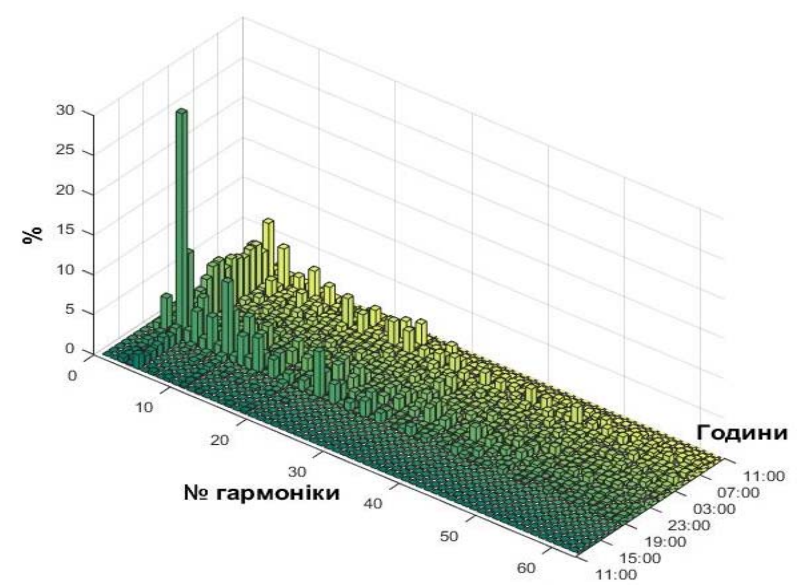

Рис. 20. Спектральний склад струму фази «А»

(C) Сиченко В. Г. та ін., 2017 


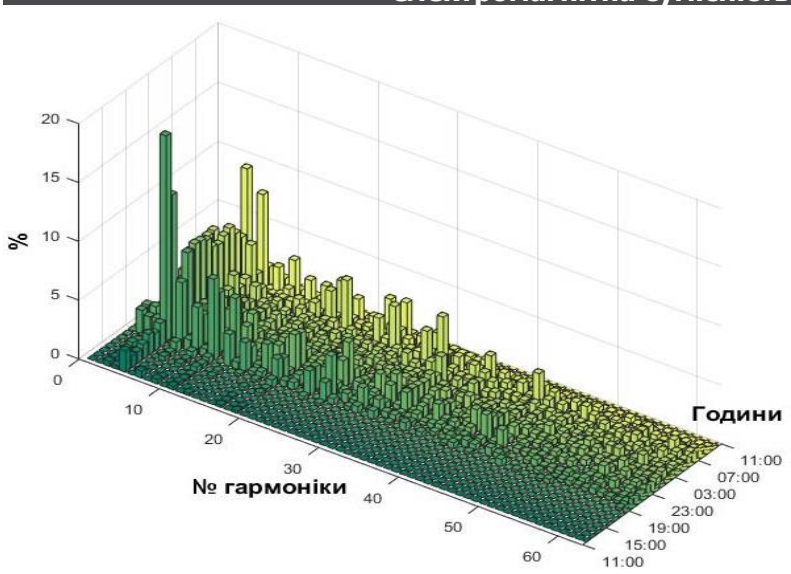

Рис. 21. Спектральний склад струму фази «B»

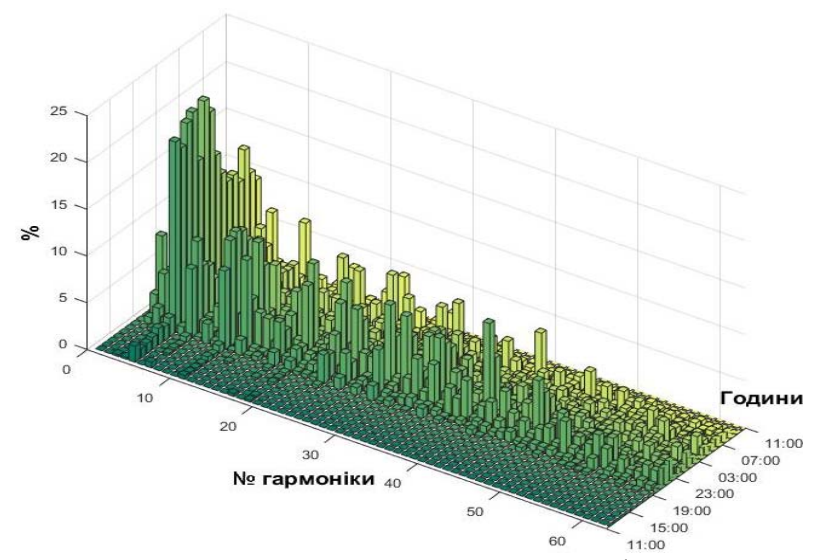

Рис. 22. Спектральний склад струму фази «C»

При роботі СЕС гармонійні складові в струмі майже не спостерігаються, а при припиненні генерації енергії в мережу з'являсться повний спектр гармонік до 63 (рис. 20 - 22).

\section{Висновки}

Проведений аналіз показників якості електроенергії на шинах 10 кВ тягової підстанції, до яких підключена сонячна електростанція показав, що в цілому якість електричної енергії задовольняє вимогам [8]. Досліджені показники в основному знаходяться в межах нормованих значень. Лише усталене відхилення напруги перевищує як нормально так і гранично допустимий рівень, але слід зауважити, що гранично допустимий рівень перевищений під час неробочої CEC. Гармонійний аналіз показав в спектральному складі напруги превалюючими є 3 та 5 гармоніки, обумовлені роботою інверторів.

\section{СПИСОК ВИКОРИСТАНИХ ДЖЕРЕЛ}

1. Сиченко, В. Г. Інтеграція сонячної енергетики у систему тягового електропостачання постійного струму / В. Г. Сиченко // Вісник Нац. техніч. ун-ту «ХПІ». Серія: Автоматика та приладобудування: зб. наук. пр. — 2015. - № 12 (1121). — С. 364-368

2. Бацала Я. В. Аналіз показників якості електроенергії сонячної електростанції / Я. В. Бацала, І. В. Гладь, У. М. Николин // Розвідка та розробка нафтових і газових родовищ. - 2013. - № 4(49). - С. 81-90

3. Денисюк С. П. Оцінка ефективності сумісної роботи розосереджених джерел генерації електроенергії, включаючи відновлювальні, в електроенергетичних системах / С. П. Денисюк, Т. М. Базюк, Д. Г. Дерев'янко // Вісник КрНУ імені Михайла Остроградського. - 2013. - №13. - С. 54-59

4. Яндульський О. С. Моделювання i аналіз впливу сонячних електростанцій на режими роботи електричної мережі / О.С. Яндульський, О.В. Хоменко, А.А. Марченко // Наукові праці ДонНТУ. Серія: «Електротехніка і енергетика». - 2013. - №1(14). - C. 324-329

5. Бекиров Э. А. Анализ качества электрической энергии, генерируемой солнечной электростанцией в энергосистему. / Э. А. Бекиров, И.В.Романовский, С. И. Колобов // Строительство и техногенная безопасность. - 2011. - № 40. - С. 106-115

(C) Сиченко В. Г. та ін., 2017

\section{REFERENCES}

1. Sychenko, V. H. Intehratsiya sonyachnoyi enerhetyky u systemu tyahovoho elektropostachannya postiynoho strumu [The integration of solar energy into DC electrical traction system] Visnyk Nats. tekhnich. untu «KhPI». Seriya: Avtomatyka ta pryladobuduvannya: zb. nauk. pr. [Bulletin of the National Technical University "KhPI" Series: Automation and Instrumentation] 2015. Vol. 12 (1121). pp. 364-368

2. Batsala Ya. V., Hlad' I. V., Nykolyn U. M. Analiz pokaznykiv yakosti elektroenerhiyi sonyachnoyi elektrostantsiyi [Analysis of electricity quality indicators of the solar power plant]. Rozvidka ta rozrobka naftovykh i hazovykh rodovyshch [Exploration and development of oil and gas fields]. 2013. Vol. 4(49). pp. 81-90

3. Denysyuk S. P., Bazyuk T. M., Derev"yanko D. H. Otsinka efektyvnosti sumisnoyi roboty rozoseredzhenykh dzherel heneratsiyi elektroenerhiyi, vklyuchayuchy vidnovlyuval'ni, v elektroenerhetychnykh systemakh [Estimation of the efficiency of the joint operation of distributed sources of electricity generation, including renewable, in electric power systems]. Visnyk KrNU imeni Mykhayla Ostrohrads'koho [Bulletin of the KrNU named after Mikhail Ostrogradsky]. 2013. Vol. 13. pp. 54-59

4. Yandul's'kyy O.S., Khomenko O.V., Marchenko A.A. Modelyuvannya i analiz vplyvu sonyachnykh elektrostantsiy na rezhymy roboty elektrychnoyi merezhi 
6. Проведення досліджень та розробка рекомендацій щодо особливостей приєднання сонячних та вітрових електростанцій до тягових підстанцій електрифікованих залізниць / Звіт з науково-дослідної роботи, № держреєстрації 0113U007948. - ДНУЗТ, Дніпропетровськ, 2014. - 148 с

7. Сиченко, В. Г. Якість електричної енергії у тягових мережах електрифікованих залізниць. / В. Г. Сиченко, Ю. Л. Саєнко, Д. О. Босий. - Д.: ПФ Стандарт-Сервіс, 2015. - 344 с

8. ГОСТ 13109-97. Норми якості електричної енергії в системах електропостачання загального призначення. - К.: Держстандарт, 1999. - 24 с.

Надійшла до друку 24.05.2017.
[Modeling and analysis of the influence of solar power plants on the operating modes of the power grid] Naukovi pratsi DonNTU. Seriya: «Elektrotekhnika i enerhetyka» [Scientific works of DonNTU. Series: Electrical engineering and power engineering]. 2013. Vol. 1(14). pp. 324-329

5. Bekyrov E.A., Romanovskyy Y.V., Kolobov S.Y. Analyz kachestva elektrycheskoy enerhyy, heneryruemoy solnechnoy elektrostantsyey v enerhosystemu. [Analysis of the quality of electric energy generated by the solar power station in the power system] Stroytel'stvo i tekhnohennaya bezopasnost' [Construction and technogenic safety]. 2011. Vol. 40. pp. 106-115

6. Provedennya doslidzhen' ta rozrobka rekomendatsiy shchodo osoblyvostey pryyednannya sonyachnykh ta vitrovykh elektrostantsiy do tyahovykh pidstantsiy elektryfikovanykh zaliznyts' [Conducting research and development of recommendations on the peculiarities of the connection of solar and wind power plants to traction substations of electrified railways] Zvit z naukovo-doslidnoyi roboty [Report on research work], № derzhreyestratsiyi 0113U007948. - DNURT, Dnipropetrovs'k, 2014. - 148 P.

7. Sychenko, V. H. Sayenko Yu. L., Bosyy D. O. Yakist' elektrychnoyi enerhiyi u tya-hovykh merezhakh elektryfikovanykh zaliznyts' [Quality of electric energy in traction networks of electrified railways]. Dnipropetrovsk.: Standart-Servis Publ., 2015. 344 P.

8. HOST 13109-97. Normy yakosti elektrychnoyi enerhiyi v systemakh elektropostachannya zahal'noho pryznachennya [Norms of quality of electric energy in general-purpose power systems]. - Kyiv.: Derzhstandart, 1999. $24 \mathrm{P}$

Внутрішній рецензент Гетьман Г. К.

Зовнішній рецензент Денисюк С. П.

У даній роботі проведено аналіз показників якості електричної енергії на шинах 10 кВ тягової підстанції при паралельній роботі з сонячною електростанцією. На основі дослідження літературних джерел та власного досвіду наведені переваги та недоліки роботи сонячної електростанції на енергосистему від якої отримує живлення тягова підстанція. Наведена схема проведення експерименту та представлені отримані результати. Виконаний статистичний та спектральний аналіз.

Ключові слова: якість електроенергії, тягова підстанція, сонячна електростанція, інвертор, рівень напруги, статистичний аналіз.

\section{УДК 621.331.3}

В. Г. СЫЧЕНКО (ДНУЖТ), Е. Н. КОСАРЕВ (ДНУЖТ), Н. Н. ПУЛИН (РЕГИОНАЛЬНЫЙ ФИЛИАЛ «ЛЬВОВСКАЯ ЖЕЛЕЗНАЯ ДОРОГА» ОАО «УКРЗАЛИЗНЫЦА»)

Днепропетровский национальный университет железнодорожного транспорта имени академика В. Лазаряна 49010, Днепр, ул. Лазаряна, 2, тел. +38 (056) 793-19-11, e-mail: elpostz@i.ua

Днепропетровский национальный университет железнодорожного транспорта имени академика В. Лазаряна 49010, Днепр, ул. Лазаряна, 2, тел. +38 (056) 793-19-11, e-mail: kosarev@e.diit.edu.ua, http://orcid.org/0000-0003-3574-7414

Региональный филиал «Львовская железная дорога» ОАО «Укрзализныця», 79000 Украина, Львов, ул. Гоголя, 1

\section{КАЧЕСТВО ЭЛЕКТРИЧЕСКОЙ ЭНЕРГИИ НА ШИНАХ 10 КВ ПРИ ПАРАЛЛЕЛЬНОЙ РАБОТЕ ТЯГОВОЙ ПОДСТАНЦИИ С СОЛНЕЧНОЙ ЭЛЕКТРОСТАНЦИЕЙ}


В данной работе проведен анализ показателей качества электрической энергии на шинах 10 кВ тяговой подстанции при параллельной работе с солнечной электростанцией. На основе исследования литературных источников и собственного опыта приведены преимущества и недостатки работы солнечной электростанции на энергосистему от которой получает питание тяговая подстанция. Приведенная схема проведения эксперимента и представлены полученные результаты. Выполнен статистический и спектральный анализ.

Ключевые слова: качество электроэнергии, тяговая подстанция, солнечная электростанция, инвертор, уровень напряжения, статистический анализ.

Внутренний рецензент Гетьман Г. К.

Внешний рецензент Денисюк С. П.

\section{UDC 621.331.3}

\section{G. SYCHENKO (DNURT), YE. M. KOSARIEV (DNURT), M. M. PULIN (REGIONAL} BRANCH "LVIV RAILWAY" JSC "UKRZALIZNYTSIA”)

Dnipropetrovsk National University of Railway Transport named after Academician V. Lazarian 49010, Dnipro, st. Lazarian, 2, tel. 38 (056) 793-19-11, e-mail: elpostz@i.ua

Dnipropetrovsk National University of Railway Transport named after Academician V. Lazarian 49010, Dnipro, st. Lazarian, 2, tel. 38 (056) 793-19-11, e-mail: kosarev@e.diit.edu.ua, http://orcid.org/0000-0003-3574-7414

Regional branch "Lviv Railway" JSC "Ukrzaliznytsia", 79000 Ukraine, Lviv, Gogol st., 1

\section{POWER QUALITY OF THE TRACTION SUBSTATION ON 10KV BUS WITH PARALLEL WORK OF THE SOLAR POWER STATION}

The power quality of the traction substation on $10 \mathrm{kV}$ bus with parallel work of the solar power station was analyzed in this paper. According to the literature resource and own experience there are advantages and disadvantages of the solar power station work on the energy system, which feeds the traction substation. There is a diagram of experiment and its results. There is also statistical and spectral analysis.

Keywords: power quality, traction substation, solar power plant, inverter, voltage level, statistical analysis.

Internal reviewer Getman G. K.

External reviewer Denisyuk S. P.

(C) Сиченко В. Г. та ін., 2017 